\title{
Performance of a demonstration solar PVT assisted heat pump system with cold buffer storage and domestic hot water storage tanks
}

\author{
Dannemand, Mark; Perers, Bengt; Furbo, Simon
}

Published in:

Energy and Buildings

Link to article, DOI:

10.1016/j.enbuild.2018.12.042

Publication date:

2019

Document Version

Peer reviewed version

Link back to DTU Orbit

Citation $(A P A)$ :

Dannemand, M., Perers, B., \& Furbo, S. (2019). Performance of a demonstration solar PVT assisted heat pump system with cold buffer storage and domestic hot water storage tanks. Energy and Buildings, 188, 46-57. https://doi.org/10.1016/j.enbuild.2018.12.042

\section{General rights}

Copyright and moral rights for the publications made accessible in the public portal are retained by the authors and/or other copyright owners and it is a condition of accessing publications that users recognise and abide by the legal requirements associated with these rights.

- Users may download and print one copy of any publication from the public portal for the purpose of private study or research.

- You may not further distribute the material or use it for any profit-making activity or commercial gain

- You may freely distribute the URL identifying the publication in the public portal 


\section{Accepted Manuscript}

Performance of a demonstration solar PVT assisted heat pump system with cold buffer storage and domestic hot water storage tanks

Mark Dannemand, Bengt Perers, Simon Furbo

PII: S0378-7788(18)33127-X

DOI: https://doi.org/10.1016/j.enbuild.2018.12.042

Reference: ENB 9029

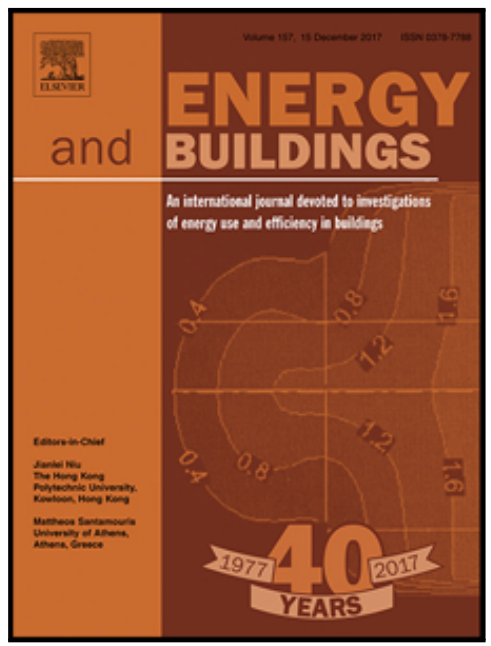

To appear in:

Energy \& Buildings

Received date:

8 October 2018

Revised date:

26 November 2018

Accepted date:

13 December 2018

Please cite this article as: Mark Dannemand, Bengt Perers, Simon Furbo , Performance of a demonstration solar PVT assisted heat pump system with cold buffer storage and domestic hot water storage tanks, Energy \& Buildings (2019), doi: https://doi.org/10.1016/j.enbuild.2018.12.042

This is a PDF file of an unedited manuscript that has been accepted for publication. As a service to our customers we are providing this early version of the manuscript. The manuscript will undergo copyediting, typesetting, and review of the resulting proof before it is published in its final form. Please note that during the production process errors may be discovered which could affect the content, and all legal disclaimers that apply to the journal pertain. 


\section{Performance of a demonstration solar PVT assisted heat pump system with cold buffer storage and domestic hot water storage tanks}

Authors: Mark Dannemand, Bengt Perers and Simon Furbo

DTU Civil Engineering, Technical University of Denmark, Brovej, Building 118, DK-2800, Kgs. Lyngby, Denmark

Corresponding author: Mark Dannemand, markd@byg.dtu.dk

Keywords: Solar assisted heat pump; Photovoltaic thermal collector; heat storage, Domestic hot water; system demonstration; energy absorber

\section{Abstract}

The design and demonstration of a solar PVT assisted - heat pump system with a cold buffer storage tank on the source side of the heat pump and a hot storage tank for domestic hot water preparation is presented. The system was subject to real weather conditions and hot water draw offs.

Measurements over nine months are presented and analysed. The focus was on the thermal dynamic of the system and the interplay between the heat pump, the storage tanks and the thermal absorber of the uninsulated PVT panel. The hot water demand was almost completely covered by the thermal part of the PVT collector in sunny summer periods. In less sunny periods, the brinewater heat pump recharged the hot water tank after draw offs and discharged the buffer storage tank. The uninsulated PVT collector worked as an energy absorber and was able to extract heat form the ambient air and recharge the buffer storage tank to the ambient air temperature when no solar irradiance was available. In the less sunny and colder periods, the PVT added a significant amount of energy to the cold storage tank.

\section{Introduction}

The energy generation from volatile renewable sources such as solar energy needs to be matched with the more stable and predictable energy demands of households. Energy storage and control strategies can be used to match the energy from the incoming solar radiation with the demands in a more efficient way. A Smart interplay between the components in such a system allows for utilizing the components most efficiently and thereby reducing energy losses.

Photovoltaics (PV) are used to generate electricity from solar irradiance. The efficiency of a PV panel drops proportionally as the temperature of the cells increases. Solar thermal collectors are used to convert the solar irradiation into heat that can be used to cover space heating and domestic hot water (DHW) demands. Combining the two principles in one hybrid photovoltaic - thermal collector (PVT) allows for removing excess heat from the PV to increase its efficiency while utilizing the removed heat to cover a heat demand. This leads to a better utilization of the solar exposed area available for the installation. Also the materials used to fabricate the hybrid PVT panel may be reduced compared to individual PV and thermal systems side by side.

Heat pumps are an efficient way of converting electricity into heat and can be used as an auxiliary heating source in solar heating systems. The heat pump needs to deliver heat at a temperature specified e.g. for space heating or DHW demands. With a fixed temperature requirement for the 
heat pump, the efficiency of the heat pump cycle depends on the temperature level of the cold side of the heat pump. Heat pumps used to cover DHW demands in residential buildings are typically airto-water or brine-to-water heat pumps. Air-to-water heat pumps typically use the ambient air as the source on the cold side whereas a brine-to-water heat pump typically has a brine loop coupled to a ground-source heat exchanger. Generally air-to-water heat pumps are less efficient over the whole year compared to brine-to-water heat pumps [1]. This is because in the periods with the highest heat demands for space heating the outdoor air temperature is significantly lower than the ground temperature, which is the source for the brine-to-water heat pump. The drawback of the heat pump with the ground-source heat exchanger is the higher installation costs and space requirement for the installation [2].

Wind and infrared sensitive solar collectors (WISC) can be used as heat exchangers between the ambient air and the heat transfer fluid in a system in periods without solar radiation. In this article, this is referred to as an energy absorber, which is defined as a device for absorbing thermal energy from the ambient when there is no significant solar radiation available. . This allows for extracting low temperatures heat from the ambient when no solar radiation is available. For a solar assisted heat pump (SAHP), a solar collector is typically used to boost the temperature on the cold side of the heat pump to increase the instantaneous COP of the heat pump. If a storage is implemented between the collector and the heat pump, it will be possible to store heat from a sunny period where the heat pump is not in operation to periods without solar radiation and colder air temperatures where the heat pump need to run. This can give the heat pump better operating conditions and lead to a better system performance. Therefore implementing buffer storage can potentially improve the seasonal performance of a solar assisted heat pump system. In the presented system design, the source for the brine-to-water heat pump is indirectly the air in periods without solar radiation when the PVT collectors work as energy absorber. In the days following periods with solar radiation, the source for the heat pump is the heat extracted by the solar collectors that is stored in the buffer storage. This leaves out the need for the ground heat exchanger of the typical ground sourced heat pump system or the air-to-water heat exchanger of the air-to-water heat pump system. In typical SAHP systems with ground sourced heat exchangers excess heat or low temperature heat which is not used for a hot water storage or as source for the heat pump can be stored in the ground via the ground heat exchanger to regenerate the temperature in the ground after operation of the heat pump [2]. This gives the potential to store heat in the ground for a later use as the source for the heat pump and avoiding a decrease in ground temperature, which would decrease the system performance. In the presented system design excess heat from the PVT collector that is not directly used for the hot water storage or as the source for the heat pump can be stored in the buffer storage for later use.

\subsection{State of the art}

\subsubsection{Reviews articles}

PVT technology and systems have been investigated in the last decades by several researchers. Zondag [3] presented a review of the liquid and air based PVT technology including a historical introduction and recommended further research in unglazed PVT collectors combined with heat pumps. Tiwari et al. [4] did a review on PV modules and their applications focusing on the thermal modelling and recommends PVT systems for decentralized power generation. Tyagi et al. [5] presented in a review article the advancement of the PVT technology since the start of the development and predicted the PVT technology a central role in various future energy systems. They desire a focus on lowering the cost of the PVT panels. Kumar et al. [6] reviewed the state and development of the PVT technology around the world. Their review was mainly focused on PVT 
technologies at the Indian subcontinent. Review articles of building integrated PVT were made by Xu et al. [7] and Yang and Athienitis [8]. Review articles on the development of PVT technology and systems were also made by Sathe and Dhoble [9], Aste et al. [10], Daghigh et al. [11], Michael et al. [12], AI-Waeli et al. [13] and Hasan and Sumathy [14]. IEA SHC Task 35 did early research and market surveys on PVT systems and developed early simulation models and tools for these systems [15]. Futher, IEA SHC task 60 focus on PVT systems and application of PVT collectors and new solutions in HVAC systems which is ongoing from 2018 to 2020 [16].

\subsubsection{Solar assisted heat pump systems - experimental studies}

Solar assisted heat pump systems for DHW and space heating purposes have been studied by several researchers. Both experimental investigations and numerical studies aimed to elucidate the potential and performance of various system designs under different climatic boundaries. A large number of publications was made within the IEA task 44 on solar and heat pump systems in 2010 to 2013 [17]. Asaee et al. [18] studied by simulation the performance of a SAHP system and made an economic feasibility analyses of retrofitting houses in Canada with the system. They found that the system could reduce the energy consumption of the houses. The system they studied was based on the design of Banister and Collins [19] which was a dual tank SAHP system. In their study, they validated a TRNSYS model of the two-tank system against an experimental setup of a custom-built heat pump with a circulation heater to simulate the solar collectors. Putrayudha et al. [20] studied advanced control strategies for PVT systems with ground sourced heat pump and found that applying an advanced Fuzzy Logic control resulted in significant energy savings compared to a simple on/off control strategy. Del Amo et al. [21] reported measurements from an energy system in a building in Zaragoza with PVT collector and validated a simulation model with the measured data. Fraga et al. [22] did a study on SAHP in a multifamily building, developed a numerical model of the system and conducted a sensitivity analysis for sizing the system. Dupeyrat et al. [23] characterized a prototype PVT collector and simulated the performance of a solar hot water system and concluded that the combined PVT panel had advantages over separated PV and solar thermal collectors. Qu et al. [24] studied experimentally a PVT solar heating system with a heat pump that could use either air or the fluid in the collectors for the cold side. Dai at al. [25] presented an experimental investigation of the ground coupled SAHP system. Panaras et al. [26] investigated the performance of the SAHP system for DHW and validated a model with measurements. Youssef et al. [27] did an experimental study of integrating a latent heat storage in a SAHP system for DHW production. Gautam and Andresen [28] evaluated the performance of RAcell BiPVT collectors and compared the performance of BiPVT with other solar technologies in terms of different sets of utility rates, investment costs and climatic conditions.

Kamel et al. did a review on the integration of systems with heat pumps and solar collectors. They focused on PVT and also review the concept of having the PVT collector works directly as the evaporator for the heat pump [29]. Cai et al. also presented a novel heat pump system, which has the PVT collectors directly working as evaporators for the heat pump [30]. Xu et al also presented a PVT/heat pump system with the PVT collector working as the evaporator . Futher Jie et al. [32], Keliang et al. [33] and Chow et al. [34] investigated the potential to use PVT collectors as absorbers for heat pumps.

\subsection{Scope}

This article presents the design and measurement on a demonstration of a novel PVT - heat pump system for DHW with two heat storage tanks, see figure 3. The demonstration system was installed and tested at the Technical University of Denmark and subject to real climatic conditions and automated draw offs of DHW to replicate a realistic demand. In the system configuration, the 
uninsulated PVT collector operated both as solar thermal absorber during sunny periods and as an energy absorber by extracting heat from the ambient air during periods with no solar irradiance. A cold buffer storage tank, which was charged by the thermal absorber of the PVT collector, was used as the source for the heat pump.

This system design potentially allows having a high seasonal performance factor similar to ground sourced heat pumps. However, the system does not need installing tubes in the ground but utilizes a buffer storage implemented between the collector and the heat pump.

To the best of the authors' knowledge the performance of a full demonstration system with this design of a PVT solar assisted heat pump system with a DHW storage tank and a cold storage tank have not been reported in the literature previously. Preliminary investigation of the PVT-heat pump system presented in this article was reported by Dannemand et al. [35].

The focus of the investigations was to evaluate the dynamic performance of the thermal part of the system concept and interplay between the different components of the system. The component sizes were not optimized for best thermal performance of the system. The analysis should give an understanding of the dynamic behaviour of the system concept and the different operation modes under various weather conditions. The monthly performance of the system over nine months including a full winter season is presented in this article.

\section{Method Experimental setup}

\subsection{PVT-SAHP with two storage tanks system description}

The PVT system was installed at the Lyngby campus of Technical University of Denmark near Copenhagen, Latitude $56^{\circ} \mathrm{N}$. It consisted of one uninsulated/WISC PVT collector with an total absorber gross collector area of $3.1 \mathrm{~m}^{2}$, with the $\mathrm{PV}$ cells covering $2.58 \mathrm{~m}^{2}$ of the panel, see Figure 1 . The PVT collector faced due south with a tilt of $45^{\circ}$. The PVT collector was installed with a distance of approximately $10 \mathrm{~cm}$ above the roof structure so that air could pass underneath it as well. The PV cell efficiency of the monocrystalline cells was nominally $18 \%$ at STC $\left(25^{\circ} \mathrm{C}\right.$ and $1000 \mathrm{~W} / \mathrm{m} 2$ and AM 1.5). The cells have an change in efficiency reduction of $\gamma=0.4 \%$ per K. An AEconversion microinverter INV350-60 was instafled between the PVT and the connection to the grid.

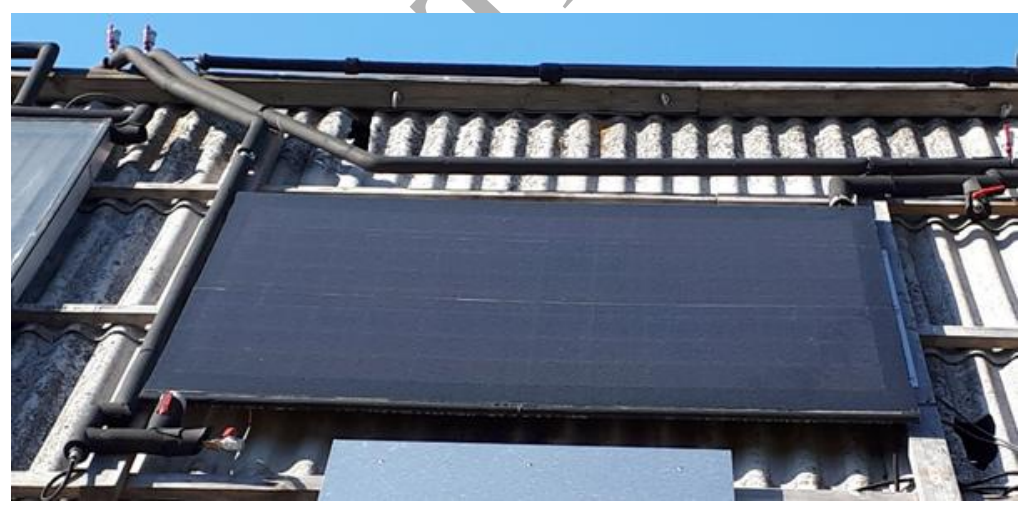

Figure 1. PVT collector installed at roof facing south with a tilt angle of $45^{\circ}$.

The thermal absorber of the PVT collector was connected in a solar collector loop to a heat exchanger spiral, with a surface area of $0.75 \mathrm{~m}^{2}$, in the bottom of a 160 litres DHW storage tank. The hydraulic loop was furthermore connected to a 200 litres "cold" buffer storage tank via a direct inlet to the tank. The solar collector loop and the cold storage tank contained a $40 \%$ propylene 
glycol/water mixture. The storage tanks were located in an indoor test facility together with the heat pump, see Figure 2.

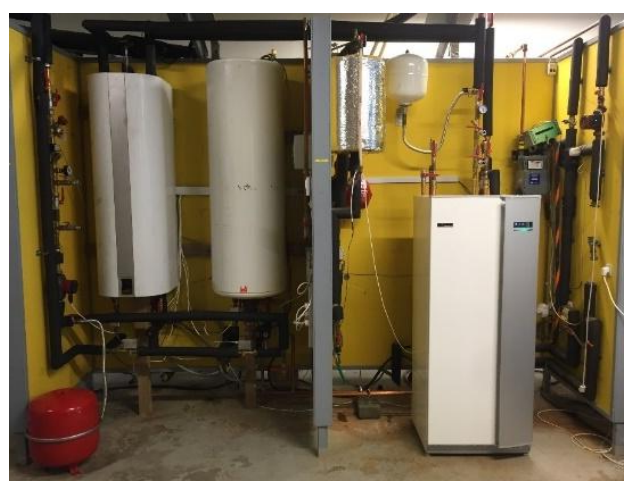

Figure 2. DHW and cold storage tanks and heat pump in indoor test facility.

As the PVT collectors were uninsulated and could work as heat exchangers with the ambient, they could still extract low temperature heat from the ambient, when no solar radiation was available. This operation mode is referred to as energy absorber.

Automated draw offs of hot water were made three times per day to simulate an actual installation in a house. $1.5 \mathrm{kWh}$ of energy was tapped three times per day at 7, 12, $18 \mathrm{hr}$. This corresponds to three times approximately 45 litres of water at $48-51{ }^{\circ} \mathrm{C}$ when the cold-water inlet temperature was $18-20^{\circ} \mathrm{C}$. In some months, the tapped energy was down to $1.1 \mathrm{kWh}$ per tapping due to clogged filters in the tapping loop which caused a reduced flow rate during the tapping.

A Vølund F1155-6 heat pump was used to heat the DHW tank when the heat from the solar collectors was insufficient to maintain the required temperature level. The heat pump is with a frequency regulated compressor. The supplier specified thermal power at $0 / 35^{\circ} \mathrm{C}$ is $3.15 \mathrm{~kW}$ with an electrical power consumption of $0,67 \mathrm{~kW}$ at $50 \mathrm{~Hz}$. This corresponds to approximately $1 \mathrm{~m}^{2} \mathrm{PVT}$ area per kW thermal power of the heat pump. This heat pump was designed to cover both a space heating and domestic hot water demand. In the present study, the system was only used for DHW. The heat pump was therefore oversized for the demonstration system presented in this article. The performance of the heat pump in this system should therefore not be evaluated in other ways than to prove the system concept. A cold buffer storage tank was used as the source for the cold side of the heat pump. The thermal absorber of the PVT panels could charge both tanks. When high temperature heat was generated in the PVT collector, it was transferred to the DHW tank and when the temperature in the PVT collector was lower than the demand for the DHW tanks, the heat was transferred to the cold buffer storage tank.

The heat pump/charged the DHW tank while extracting heat from the buffer storage tank when the temperature level of the DHW tank dropped below a set value. This was typically after a tapping of DHW. As the heat pump charged the domestic hot water tank, energy was extracted from the cold storage, which could then be recharged by the PVT collectors.

The PVT collectors were connected to the tanks via $20 \mathrm{~m}$ forward and $20 \mathrm{~m}$ return copper pipes with an outer/inner diameter of 22/20 mm. The pipes were insulated with Aeroflex with a thickness of 19 $\mathrm{mm}$. The pipes between the heat pump to the storage tanks were each 4.5 meters and diameter $22 / 20 \mathrm{~mm}$. 
The PVT solar heating system was tested under real weather conditions from August 2017 to April 2018 with some periods of fall out due to maintenances and renovations issues. Table 1 lists the main components of the PVT system.

Table 1. Component overview.

\begin{tabular}{|l|l|}
\hline Component & Description \\
\hline PVT collector & $3.1 \mathrm{~m}^{2}$ PVT panel (WISC) from Racell Technologies \\
\hline DHW storage & 160 litres with two $0.75 \mathrm{~m}^{2}$ spiral heat exchangers \\
\hline Cold storage & $\begin{array}{l}\text { 200 litres with two inlets/outlets in the upper part of the } \\
\text { tank and two in the bottom part of the tank }\end{array}$ \\
\hline Heat pump & Vølund F1155-6. \\
\hline Controller & Technische Alternative UVR 63 \\
\hline Solar loop pump & Grundfos Alpha2 25-80 \\
\hline
\end{tabular}

\subsubsection{Operation and control}

An UVR 63 from "Technische Alternative" controlled the solar collector loop of the system and the internal control in the heat pump was used to maintain the required temperature level in the top of the DHW tank. Figure 3 illustrates the PVT system with the sensor locations and the control strategy of the thermal part of the solar heating system.

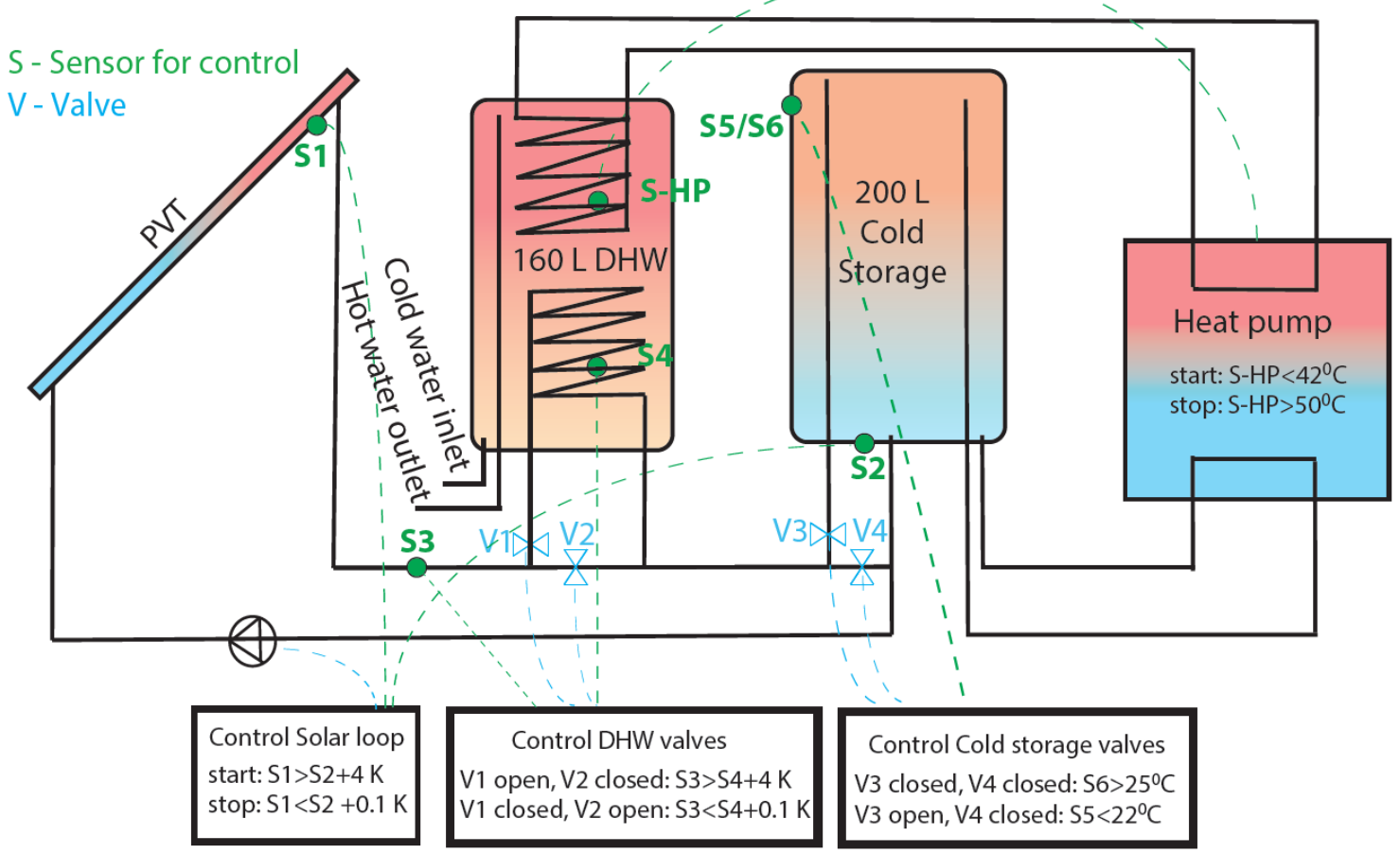

Figure 3. Illustration of the PVT system and the control strategy and sensor locations.

The design of the absorber with narrow channels did not allow for inserting a temperature sensor into the absorber to measure the temperature of the heat transfer fluid inside to PVT panel.

Therefore, the temperature of the absorber measured on the back of the PVT panel near the outlet was used for the control of the solar collector loop. When the temperature on the back of the PVT panel (S1) was $4 \mathrm{~K}$ higher than the bottom of the cold tank (S2) the flow in the collector loop started by switching on the solar collector loop pump. The pump remained on until the temperature of the 
PVT panel dropped below the temperature in the bottom of the cold tank. If the temperature in the pipe immediately before the DHW tank (S3) was $4 \mathrm{~K}$ higher than in the lower part of the DHW tank (S4), then the flow was directed through the lower heat exchanger spiral of the DHW tank by opening the valve V1 and closing the valve V2. When the temperature in the pipe before the DHW tank dropped to the same level as in the lower part of the DHW tank, then the flow bypassed the DHW tank by closing V1 and opening V2. As long as the temperature in the top of the buffer tank $(\mathrm{S} 5 / \mathrm{S} 6)$ was below $25^{\circ} \mathrm{C}$, then the flow of the solar collector loop was directed through the buffer storage tank by having the valves V3 open and V4 closed. Otherwise, it was bypassed. This maximum temperature in the cold tank was due to the maximum allowed inlet temperature in the cold side of the heat pump of $30^{\circ} \mathrm{C}$.

This control strategy allowed the collector loop to run even though heat was not transferred to any tank. This was when the buffer storage tank was fully heated to $25^{\circ} \mathrm{C}$, the temperature in the PVT was higher than the buffer tank and the temperature in the bottom of the DHW tank was higher than in the PVT. A more advanced control strategy could have avoided this.

When the temperature in the top of the DHW tank (S-HP) dropped below $42{ }^{\circ} \mathrm{C}$, then the heat pump started and charged the top of the DHW tank to $50^{\circ} \mathrm{C}$ via the top spiral. When the heat pump discharged the cold tank and the temperature in the cold tank dropped below the ambient temperature, the PVT collectors operated as energy absorbers and were used to extract heat from the ambient and recharge the buffer storage tank. This could be done even when no significant solar irradiance was available.

\subsection{Measurements}

Absolute temperatures at various key locations in the PVT panel, tanks and liquid flow temperatures in the pipes (T1 - T31), temperature differences $(d(2-3))$, flow rates (F1-F3, F7), electricity generation and electricity consumption (P1, P2) at various key locations in the system and ambient were measured and logged. Five junction thermopiles made from thermocouples type TT were used to determine the temperature differences across in- and outlet of the collectors as well as across the hot and cold-water temperatures for the domestic hot water tapping. The total and the diffuse irradiances on the PVT panel were measured by CMP11 Kipp \& Zonen pyranometers. Kamstrup and Brunata flow meters were used to measure the flow in the different loops. Thermocouples type TT were used to measure temperatures. A National Instrument cRIO was used for the measurement and data logging.

Figure 4 shows an overview of the location of the thermocouples, thermopiles, flow meters and power meters in the system as well as the weather data measurements.

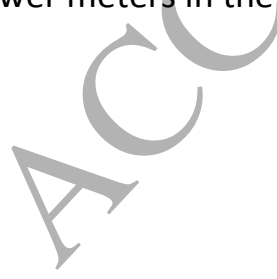




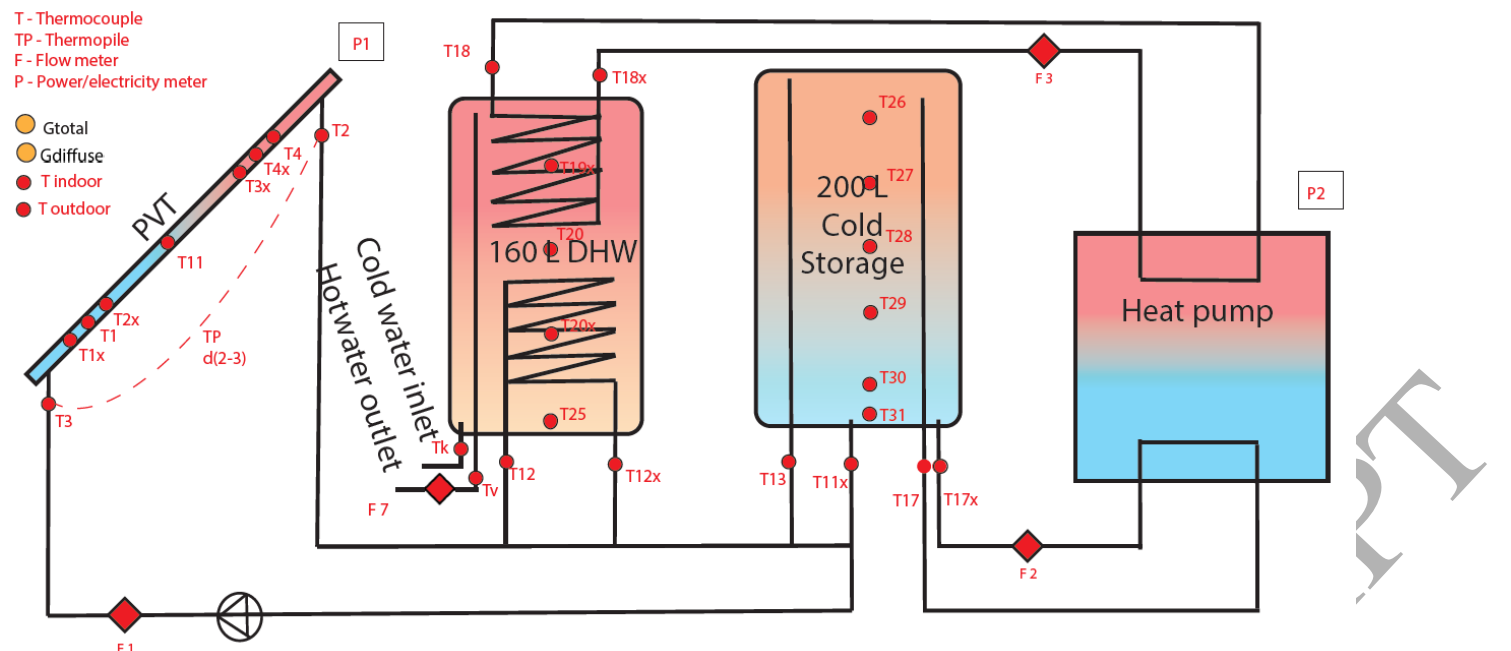

Figure 4. Overview of measurement equipment. Location of temperature sensors $(T)$, flow meters $(F)$, energy meters $(P)$ and pyranometers $(G)$.

Some days of measurements were lost due to faulty valves in the hydraulic loop of the system and maintenance of the measurement and data logging equipment. Table 2 lists the number of days with complete measurements that were used for the performance analysis.

Table 2. Days with complete measurements used for the performance analysis.

\begin{tabular}{|l|l|l|l|l|l|l|l|l|l|}
\hline & Aug & Sep & Oct & Nov & Dec & Jan & Feb & Mar & Apr \\
2017 & 2017 & 2017 & 2017 & 2017 & 2018 & 2018 & 2018 & 2018 \\
\hline $\begin{array}{l}\text { No. of days with } \\
\text { measurements }\end{array}$ & 25 & 30 & 31 & 30 & 31 & 27 & 27 & 31 & 12 \\
\hline
\end{tabular}

\subsection{Analysis method}

The energy flows for the various loops were determined for each minute and key values were summarized for each month. Average values of a day for each month is presented to compensate for incomplete measurements periods in some months.

In the analysis, it was considered to be energy absorber operation when the solar radiation level Gtotal was below $50 \mathrm{~W} / \mathrm{m}^{2}$ and traditional solar thermal collector operation when the solar radiation level was higher than $50 \mathrm{~W} / \mathrm{m}^{2}$.

The energy consumption of the pump for the solar collector loop was calculated with an average power for the pump of $6 \mathrm{~W}$. The direct usage of the PV produced electricity by the heat pump and the solar collector loop pump was determined for each one-minute time step. For calculation purposes, the produced electricity in the PV was prioritized to be used for the collector loop pump when it was running and the excess electricity was used by the heat pump.

Two different solar fractions were used for evaluating the overall performance of the system. Solar fraction A only considers the tapped energy for the DHW drawn and the electricity consumed by the heat pump. Solar fraction B also includes the electricity produced by the PVT collector.

Solar fraction A is defined as: $S F_{A}=\frac{Q_{t a p}-E_{s y s t e m}}{Q_{t a p}}$ 
Solar fraction B is defined as: $S F_{B}=\frac{Q_{t a p}-E_{s y s t e m}+E_{P V}}{Q_{t a p}}$

where $Q_{\text {tap }}$ is the energy tapped for $D H W, E_{\text {sytem }}$ is the energy consumed by the heat pump and solar collector loop pump and $\mathrm{E}_{\mathrm{PV}}$ is the electricity produced in the PVT.

The net utilized solar energy was calculated for each month as the monthly values for the energy tapped for DHW and the electricity produced by the PVT minus the electricity used by the heat pump and collector loop pump.

Net utilized solar energy $=Q_{\text {tap }}+E_{P V}-E_{\text {system }}$

The performance factor for the system is determined for each month as $\mathrm{PF}_{\text {system }}=\frac{Q_{\text {tap }}}{E_{\text {system }}}$

\section{Results and discussions}

\subsection{Monthly performances}

\subsubsection{PVT collector performance}

Error! Reference source not found. shows the measured average daily total solar irradiation on the PVT collector for each month over the test period.andthe PVF collector output. The PVT output is divided into electrical output from the PV, thermal output when the solar irradiance was higher than $50 \mathrm{~W} / \mathrm{m}^{2}$; and the energy absorber output when the solar irradiance was lower that $50 \mathrm{~W} / \mathrm{m}^{2}$. In addition, the average cold storage tank temperature, ambient air temperature and indoor temperature at the test facility are displayed. 


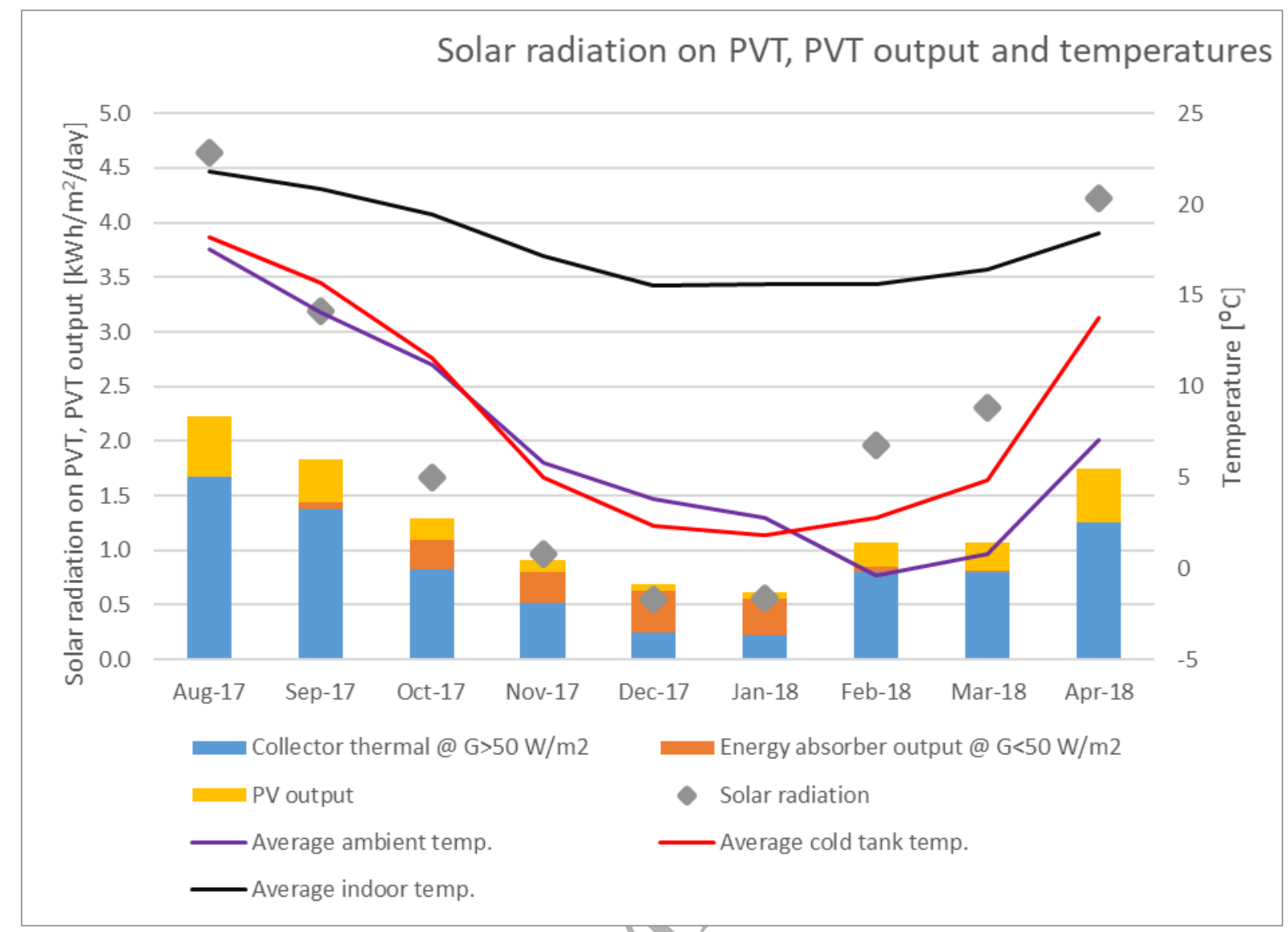

Figure 5. Measured daily average radiation on the PVT collector, PVT collector thermal, energy absorber and PV output, monthly average ambient, indoor and cold storage tank temperatures for each month of the test period.

From Error! Reference source not found. Figure 5 can be seen that the PV output and the thermal output at irradiance levels higher than $50 \mathrm{~W} / \mathrm{m}^{2}$ are relatively proportional. For each months, the overall fraction of solar irradiation on the PVT collector converted into thermal output was in the range from 30 to $50 \%$ as expected for an uninsulated collector.

December and January showed to have the highest levels of energy extracted from the ambient by the energy absorber. This was when the irradiance levels were very low and the temperature level in the cold storage tank was lower than the ambient temperature. In each month from October to January 0.8 to $1.1 \mathrm{kWh}$ of heat was transferred from the PVT in energy absorber operation to the buffer storage tank per day. In this period, the ambient temperature was slightly higher than the cold storage tank and heat transfer was possible. The energy absorber function did add a considerable amount of energy to the system in these months.

In February and the following months only very little heat was transferred to the system from the PVT collector in energy absorber operation when the irradiance was lower that $50 \mathrm{~W} / \mathrm{m}^{2}$. This was due to the ambient temperature being lower than the cold storage tank temperature and that the overall higher solar radiation level was higher which resulted in higher collector thermal yields. In the months with solar irradiation higher than $2 \mathrm{kWh} / \mathrm{m}^{2} /$ day heat was primarily transferred to the storage tanks when the irradiance was higher than $50 \mathrm{~W} / \mathrm{m}^{2}$ and the thermal part of the PVT collector worked as a traditional solar collector. 


\subsubsection{Heat pump operation}

Figure 6 shows the daily tapped energy quantities for the DHW draw offs, the energy extracted from the buffer storage (measured at T17 and T17x), the energy delivered to the DHW tank by the heat pump (measured at T18 and T18x) and the electricity consumption of the heat pump. The figure indicates that there was a significant heat loss from the system. This was due to a relatively poor designed DHW tank with pipe connections in the top of the tank and a relatively long pipe connection between the tanks and the heat pump of 4.5 meters. Also the heat pumps relatively short operation periods of 20-40 minutes several times per day lead to significant extra losses. This was when the heat pump started and the pipes between the heat pump and the tanks had to be heated and when it stopped, the hot water was left in the pipes the energy lost to the ambient.

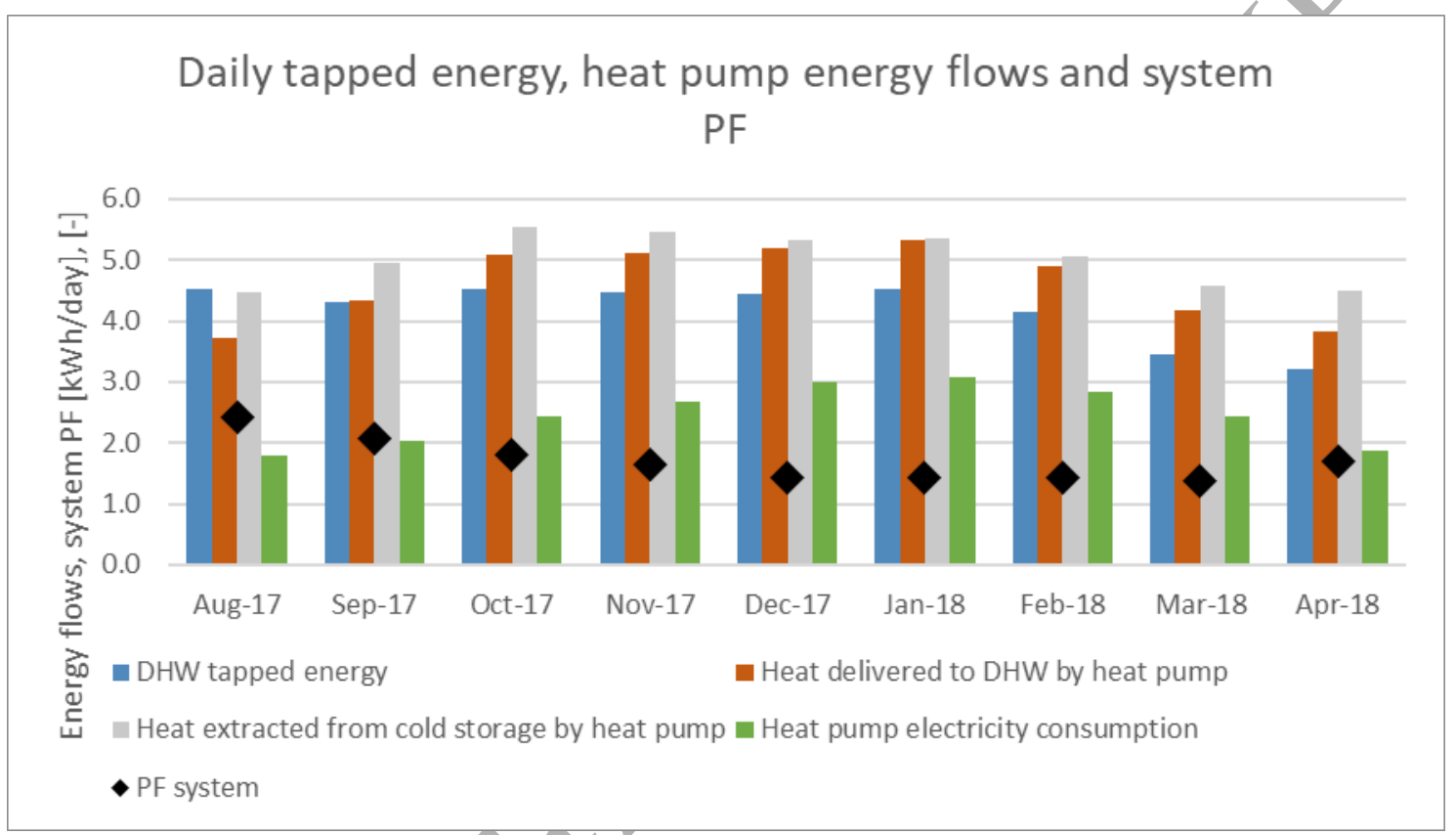

Figure 6. Daily tapped energy, energy extracted from the cold storage, heat delivered to the DHW tank and the electricity consumption by the heat pump.

\subsubsection{Collector loop operation}

Figure 7 shows that average daily operation time for the pump for the PVT collector loop. The total operation time and the periods of which the pump was running with an irradiance level lower than $50 \mathrm{~W} / \mathrm{m}^{2}$ is displayed. It shows that in the colder less sunny months of February to April the collector loop pump operated about half as much as in the rest of the period. In the sunny periods of August and September, the collector loop primarily operated as solar collector loop and in the less sunny but mild periods of October to January the PVT collector loop operated primarily as energy absorber. 


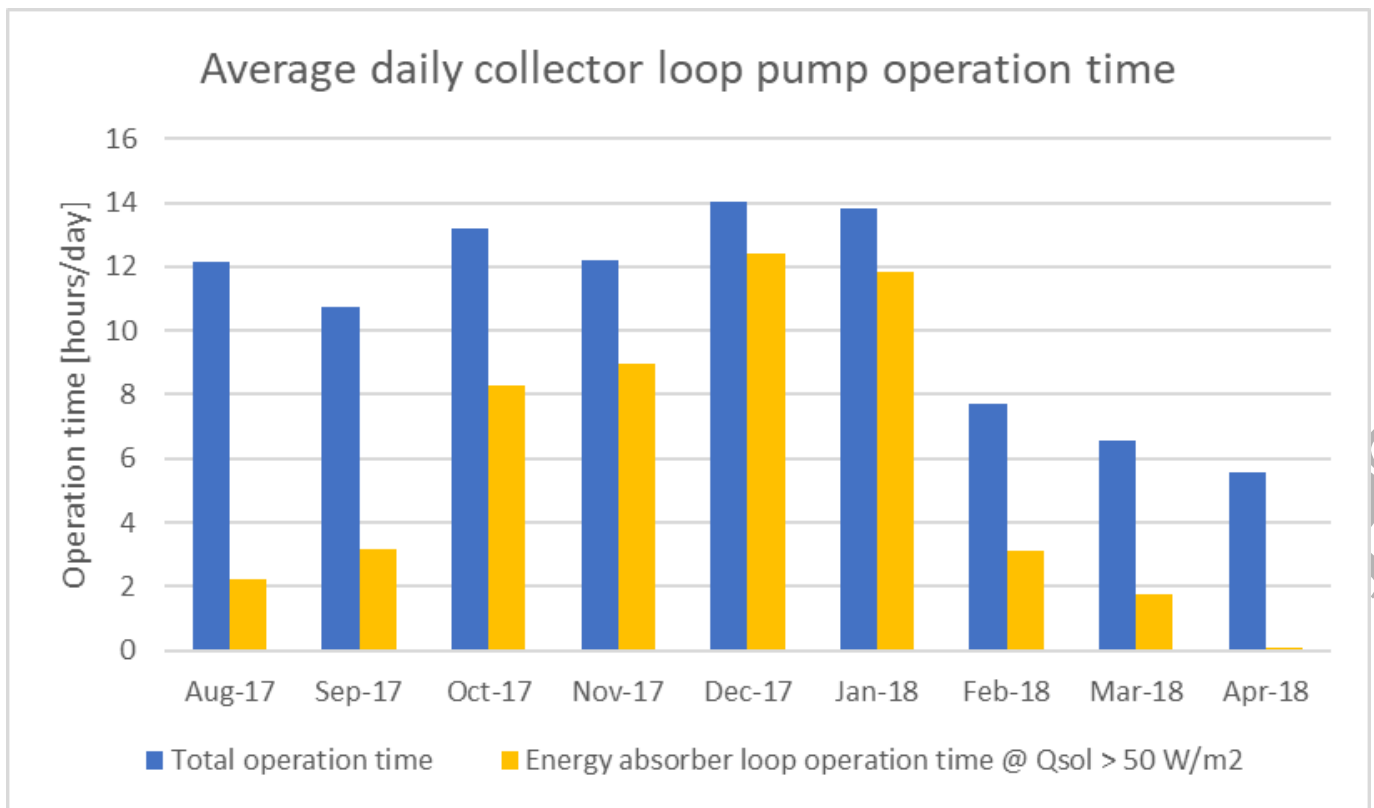

Figure 7. Average daily collector loop operation time for each month, total operation time and in energy absorber operation.

\subsubsection{Electricity usage}

Figure 8 shows the electricity consumption for the system (heat pump and collector loop pump), the produced electricity in the PV and the part of the produced electricity, which was directly used in the same minute as it was produced.

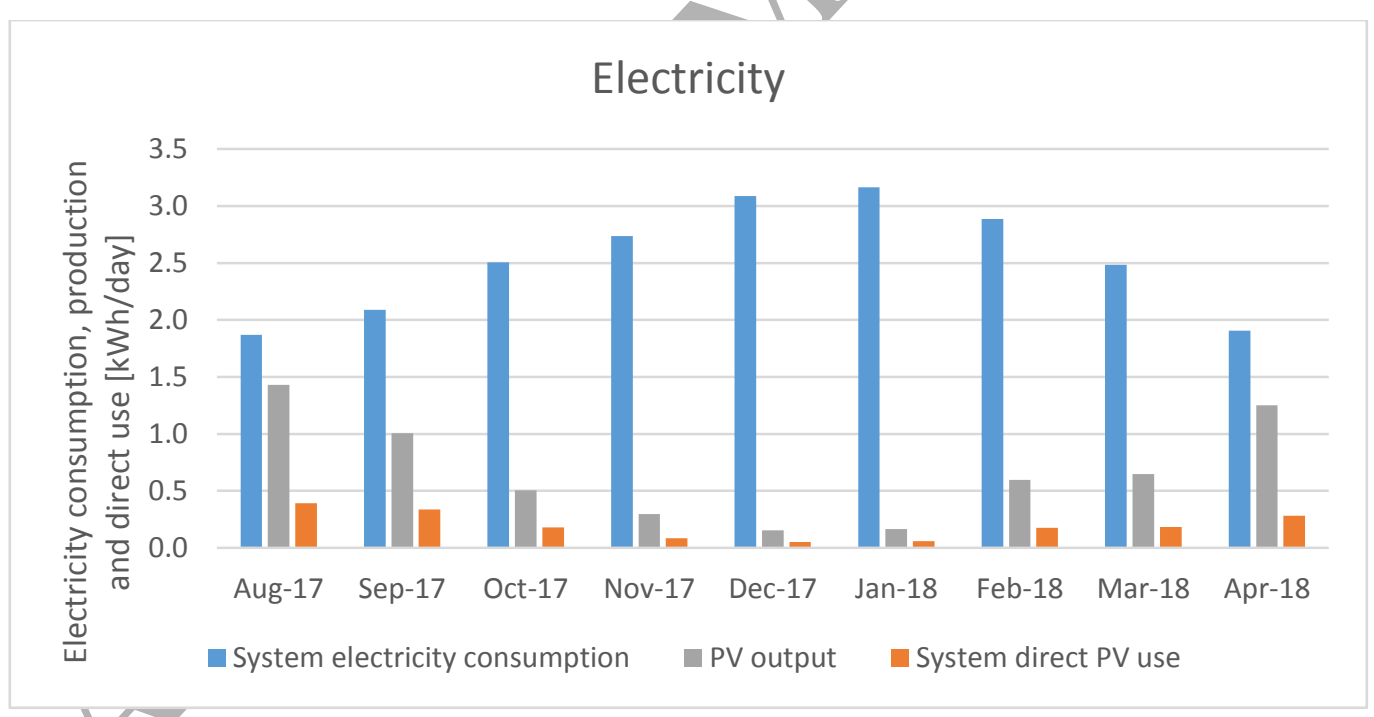

Figure 8. System electricity consumption, electricity produced in PVT and direct use.

It shows that for this size of a system, only a low fraction of the produced electricity in the PVT was consumed by the heat pump in the same period as it was generated. The main reason for this was that the heat pump operated with its own built in control independently of the solar irradiance level. A smart system control strategy may result in more direct electricity consumption if the demands were shifted to periods with high solar levels and the heat stored to periods of use. Further, for this sized specific system the power required by the heat pump was $800-1000 \mathrm{~W}$ in the summer period and $1200-1500 \mathrm{~W}$ in the winter period depending on the temperature level in the buffer storage 
tank. The installed PVT panel produced up to $330 \mathrm{~W}$ of AC electricity in sunny periods after the inverter losses. A larger PVT collector area, or a smaller heat pump could lead to more direct electricity consumption.

\subsubsection{System performance}

Figure 9 shows the system solar fraction and the net utilized solar energy. It can be seen that in the sunny periods the solar fraction is up to $90 \%$ with the potential of surpass $100 \%$ in mid-summer.

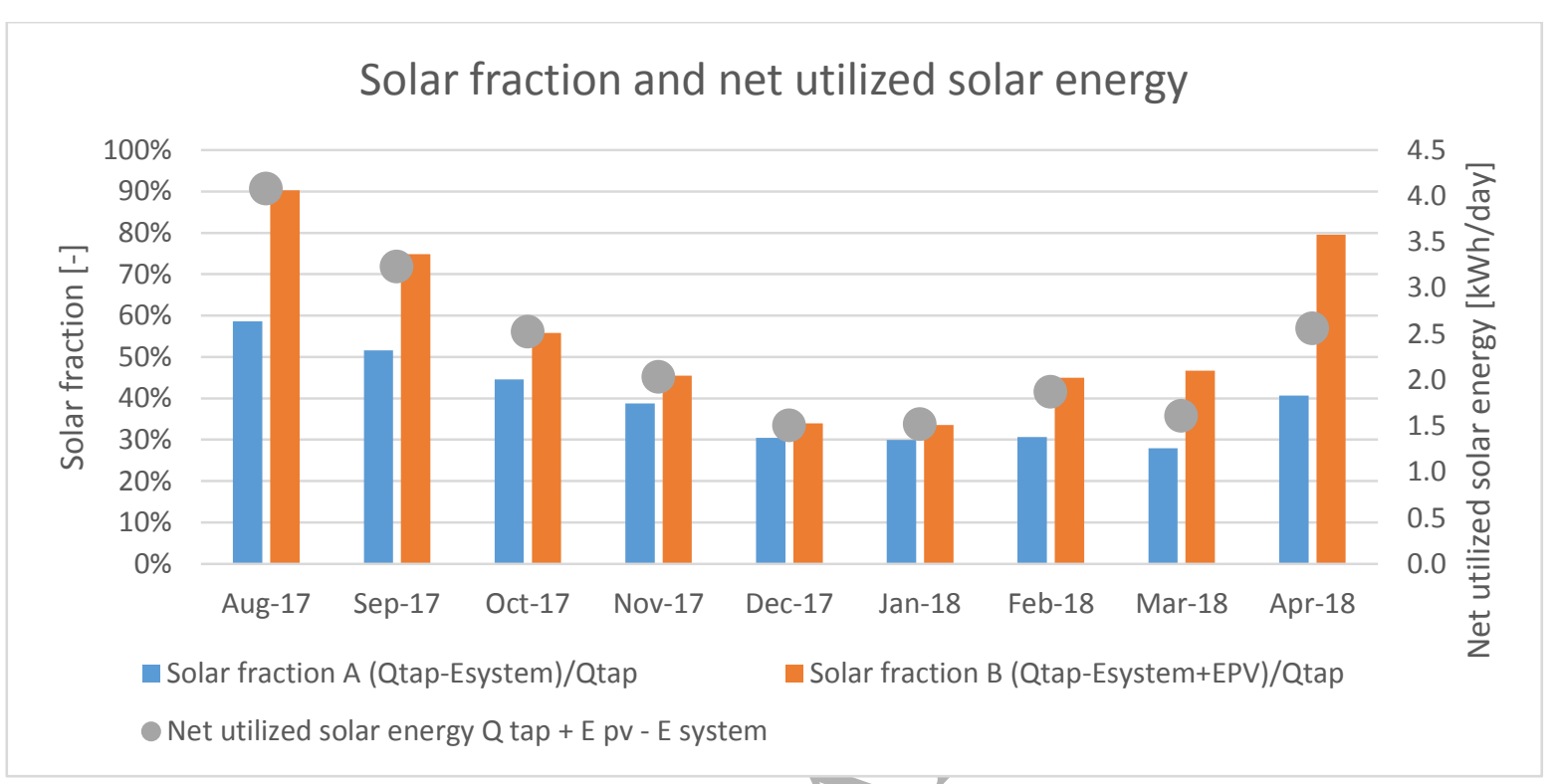

Figure 9. System solar fractions with and without electricity produced in the PVT and net utilized solar energy.

\subsection{Total values}

Table 3 shows the total accumulated values for the solar irradiation on the PVT collector, the thermal output at irradiances higher than $50 \mathrm{~W} / \mathrm{m}^{2}$, the energy absorber output, the tapped energy for the DHW draw offs and the electricity consumption for the system.

Table 3. Overview of measurements results for PVT systems performance.

\begin{tabular}{|l|l|l|l|l|l|}
\hline $\begin{array}{l}\text { Measurement } \\
\text { period }\end{array}$ & $\begin{array}{l}\text { Solar } \\
\text { irradiation } \\
\text { on PVT } \\
\text { collector }\end{array}$ & $\begin{array}{l}\text { Collector } \\
\text { output @ } \\
\mathrm{G}>50 \mathrm{~W} / \mathrm{m}^{2}\end{array}$ & $\begin{array}{l}\text { Energy } \\
\text { absorber } \\
\text { output @ } \\
\mathrm{G}<50 \mathrm{~W} / \mathrm{m}^{2}\end{array}$ & $\begin{array}{l}\text { DHW } \\
\text { tapped } \\
\text { energy }\end{array}$ & $\begin{array}{l}\text { System } \\
\text { electricity } \\
\text { consumption }\end{array}$ \\
\hline 244 days & $500 \mathrm{kWh} / \mathrm{m}^{2}$ & $208 \mathrm{kWh} / \mathrm{m}^{2}$ & $41 \mathrm{kWh} / \mathrm{m}^{2}$ & $1034 \mathrm{kWh}$ & $628 \mathrm{kWh}$ \\
\hline
\end{tabular}

Table 4 shows the total accumulated values for the electricity consumption of the heat pump, both the total and for the periods where it was in operation and in standby. In addition, the heat delivered to the DHW tank and extracted from the cold storage is listed. The estimated heat loss from the pipes between the heat pump and the DHW tanks and the losses associated with the start and stop of the heat pump is included.

Table 4. Heat pump electricity consumption, total, in operation and standby periods as well as heat delivered to DHW tank and extracted from the cold storage.

\begin{tabular}{|l|l|l|l|l|l|}
\hline $\begin{array}{l}\text { Heat pump } \\
\text { electricity } \\
\text { consumption }\end{array}$ & $\begin{array}{l}\text { In operation } \\
\text { electricity } \\
\text { consumption }\end{array}$ & $\begin{array}{l}\text { Standby } \\
\text { electricity } \\
\text { consumption }\end{array}$ & $\begin{array}{l}\text { Heat } \\
\text { delivered to } \\
\text { DHW tank }\end{array}$ & $\begin{array}{l}\text { Heat extracted } \\
\text { from cold } \\
\text { storage }\end{array}$ & $\begin{array}{l}\text { Heat loss form } \\
\text { heat pump }\end{array}$ \\
\hline
\end{tabular}




\begin{tabular}{|l|l|l|l|l|l|}
\hline $612 \mathrm{kWh}$ & $536 \mathrm{kWh}$ & $75 \mathrm{kWh}$ & $1146 \mathrm{kWh}$ & $1238 \mathrm{kWh}$ & $628 \mathrm{kWh}$ \\
\hline
\end{tabular}

Table 5 shows the electricity produced by the PVT, electricity directly used by the heat pump and the solar collector loop pump, total electricity consumption for the solar collector loop pump and the electricity delivered to the grid and used from the grid.

Table 5. Electricity produced in the PVT, electricity directly used by the heat pump and the solar collector loop pump, total electricity consumption for the solar collector loop pump and the electricity delivered to the grid and used from the grid.

\begin{tabular}{|l|l|l|l|l|l|}
\hline $\begin{array}{l}\text { Electricity } \\
\text { produced in } \\
\text { PVT (after } \\
\text { inverter) }\end{array}$ & $\begin{array}{l}\text { Heat pump } \\
\text { direct PV } \\
\text { consumption }\end{array}$ & $\begin{array}{l}\text { Collector loop } \\
\text { pump } \\
\text { electricity } \\
\text { consumption }\end{array}$ & $\begin{array}{l}\text { Collector loop } \\
\text { pump direct PV } \\
\text { consumption }\end{array}$ & $\begin{array}{l}\text { Electricity } \\
\text { to grid }\end{array}$ & $\begin{array}{l}\text { Electricity } \\
\text { from grid }\end{array}$ \\
\hline $151 \mathrm{kWh}$ & $37 \mathrm{kWh}$ & $16 \mathrm{kWh}$ & $8 \mathrm{kWh}$ & $106 \mathrm{kWh}$ & $583 \mathrm{kWh}$ \\
\hline
\end{tabular}

The electrical efficiency of the PVT was throughout the test period measured after the inverter to be up to $13.5 \%$ in sunny periods, based on total PVT panel area.

\subsection{Characteristic days / operation modes}

\subsubsection{Summer sunny operation condition - solar collector}

Figure 10 shows how the thermal part of the PVT system operated on a typical sunny day in summer. As the sun rose and the temperature in the PVT collectorincreased above the temperature in the bottom of the buffer storage tank, the solar collector loop pump started at 06:00 o'clock indicated by F1. At 07:00 there was a DHW draw off (F7) and the temperature in the DHW tank (T19x, T20, T25) dropped below the set point for the heat pump. The heat pump then charged the upper volume of the DHW tank (T19x). During the day, the PVT collector temperature increased and the DHW tank was charged from the bottom. At noon there was another DHW draw off which was covered by the heat stored in the DHW tank. In addition, the last DHW draw off of the day was covered by heat stored in the DHW tank. From 16:00 o'clock, the collector output dropped to negative due to a non-optimal control strategy for the PVT system. This was in the situation where the buffer storage was charged to its maximum temperature of $25^{\circ} \mathrm{C}$ and the temperature in the PVT was lower than in the bottom of the DHW tank. Therefore, both storage tanks were bypassed and the negative power in the collector loop represents the heat loss in the pipes between the collector and the tanks.

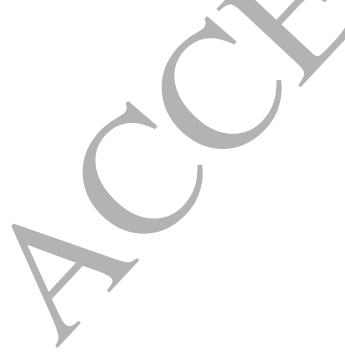




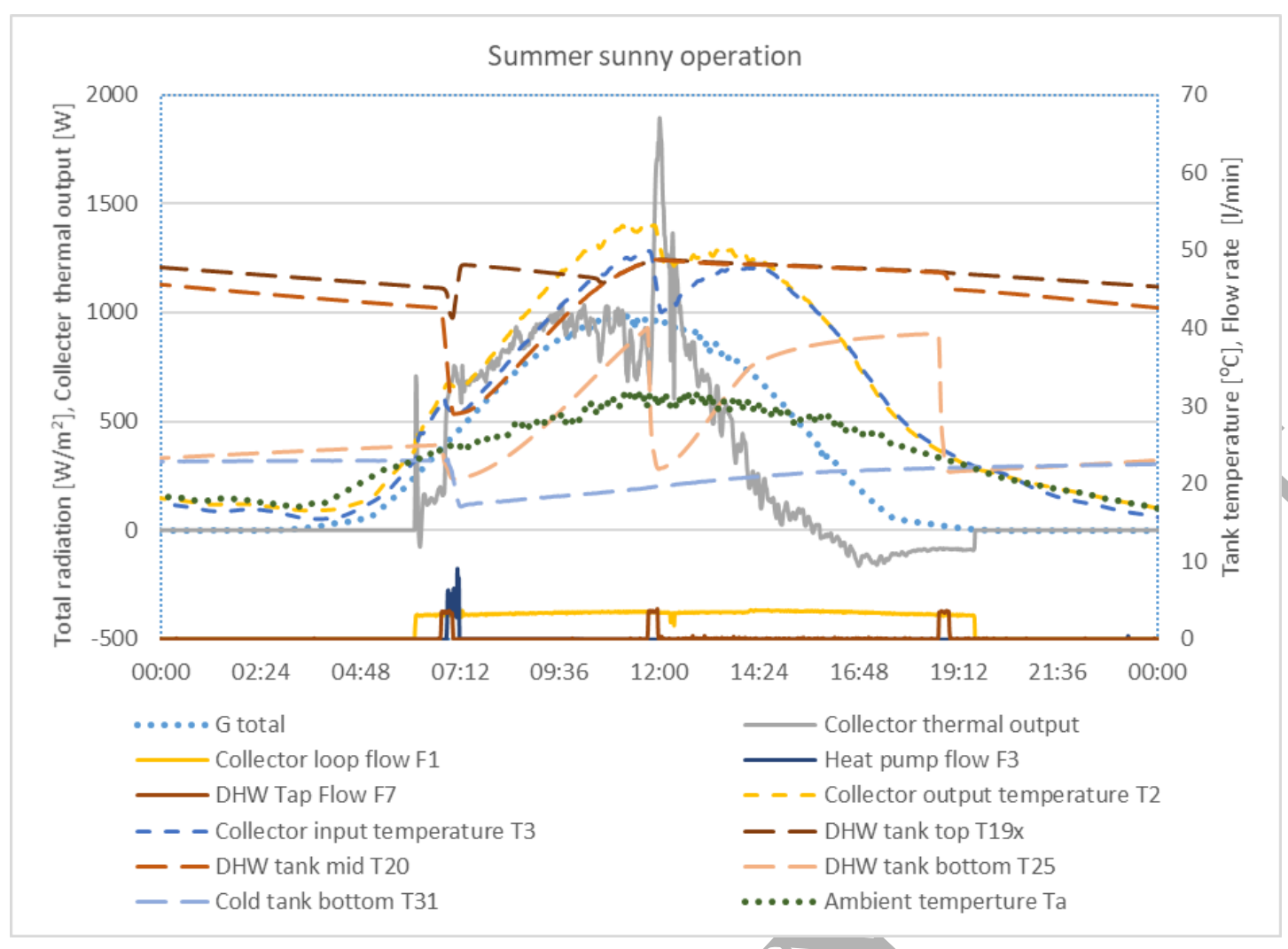

Figure 10. PVT system thermal part operations in sunny periods in summer. Collector in- and outlet temperatures, top, mid and bottom DHW tank temperatures, cold tank bottom temperature, ambient temperature flow rates in solar collector loop, heat pump loop and tapping loop, solar radiation level and thermal output of collector.

During the sunny summer period, the DHW tank was primarily heated by the thermal part of the PVT collector. Only after the DHW draw offs in the mornings where the temperature in the DHW tank dropped below the set point for the heat pump, the DHW tank had to be recharged by the heat pump. The morning draw off was before the solar irradiance level was high enough to charge the DHW tank. A control strategy including forecasting of weather conditions could potentially postpone the operation of the heat pump to let the solar collectors heat the tank.

\subsubsection{Winter night operating conditions - energy absorber}

Figure 11 show an example of how the PVT system typically operated with the PVT collector operating as energy absorber in periods with no solar irradiance. At 19:20 there was a DHW draw off (F7) and the temperature in the DHW tank dropped below the set point for the heat pump and the heat pump recharged the DHW (not shown) and discharged the cold storage tank (F3, T31). Before the DHW draw off, the ambient temperature (Ta) and the buffer storage was approximately $2.5^{0} \mathrm{C}$. As the heat pump operated (F3), the temperature in the cold storage tank (T31) dropped $5 \mathrm{~K}$ to -2.5 0 C. The temperature difference between the collector and the cold storage tank increased above the set point of $4 \mathrm{~K}$, the collector loop started (F1) and heat was transferred from the ambient to the cold storage tank. This continued until the cold tank again reached the ambient temperature of approximately $2.5^{0}$ C. Some part of the heat gain to the cold storage tank was caused by heat gain from the indoor temperature of about $16^{\circ} \mathrm{C}$. 


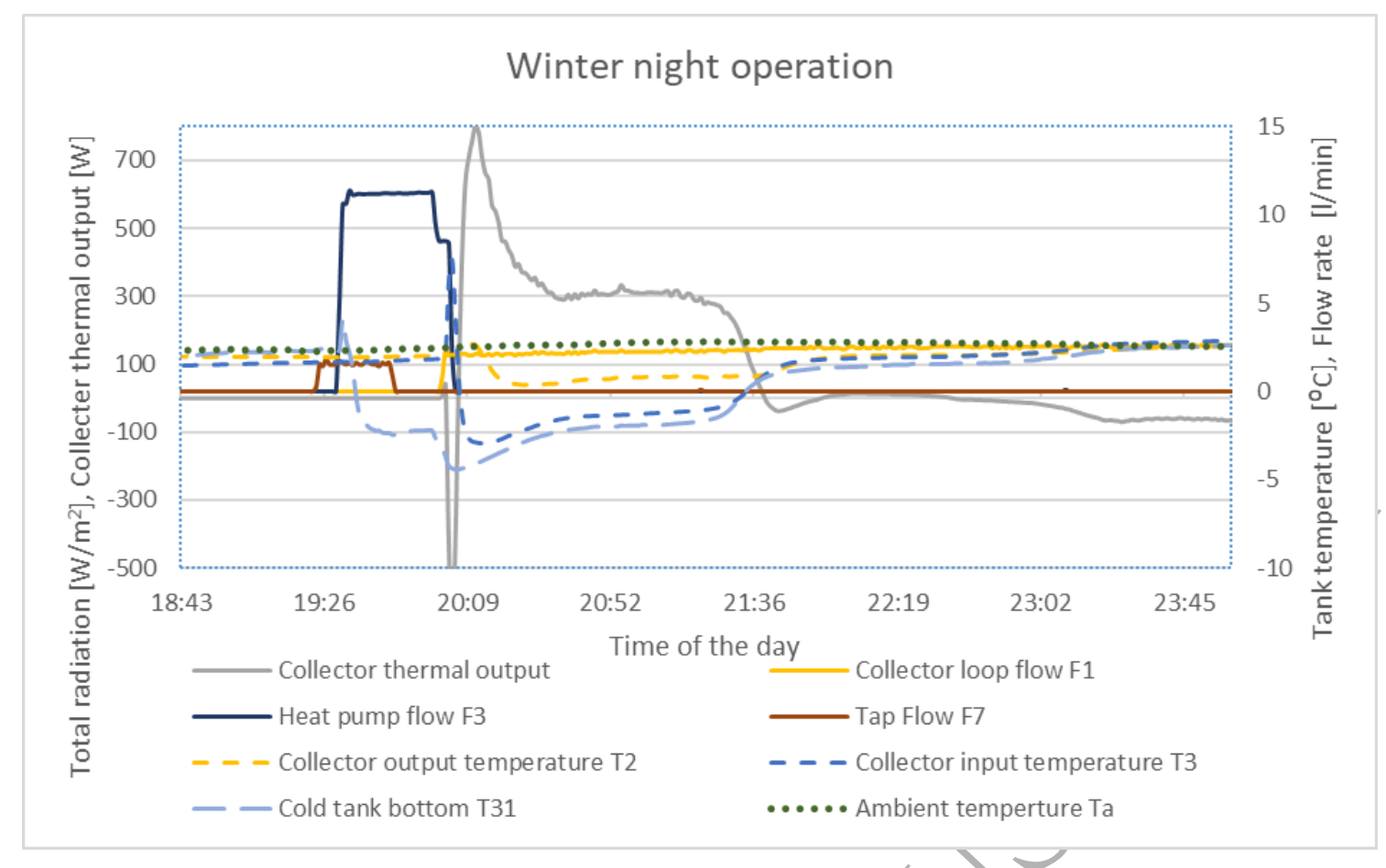

Figure 11. PVT system thermal part operations at night in winter. Collector in-and outlet temperatures, cold tank bottom temperature, ambient temperature, flow rates in solar collector loop, heat pump loop and tapping loop and thermal output of collector.

The example in Figure 11 shows how the buffer storage tank was reheated to the ambient temperature by the energy absorber of the PVT collector after being discharged by the heat pump.

\subsubsection{Winter sunny operation condition}

Figure 12 shows an example of how the system operates during a sunny winter day. 


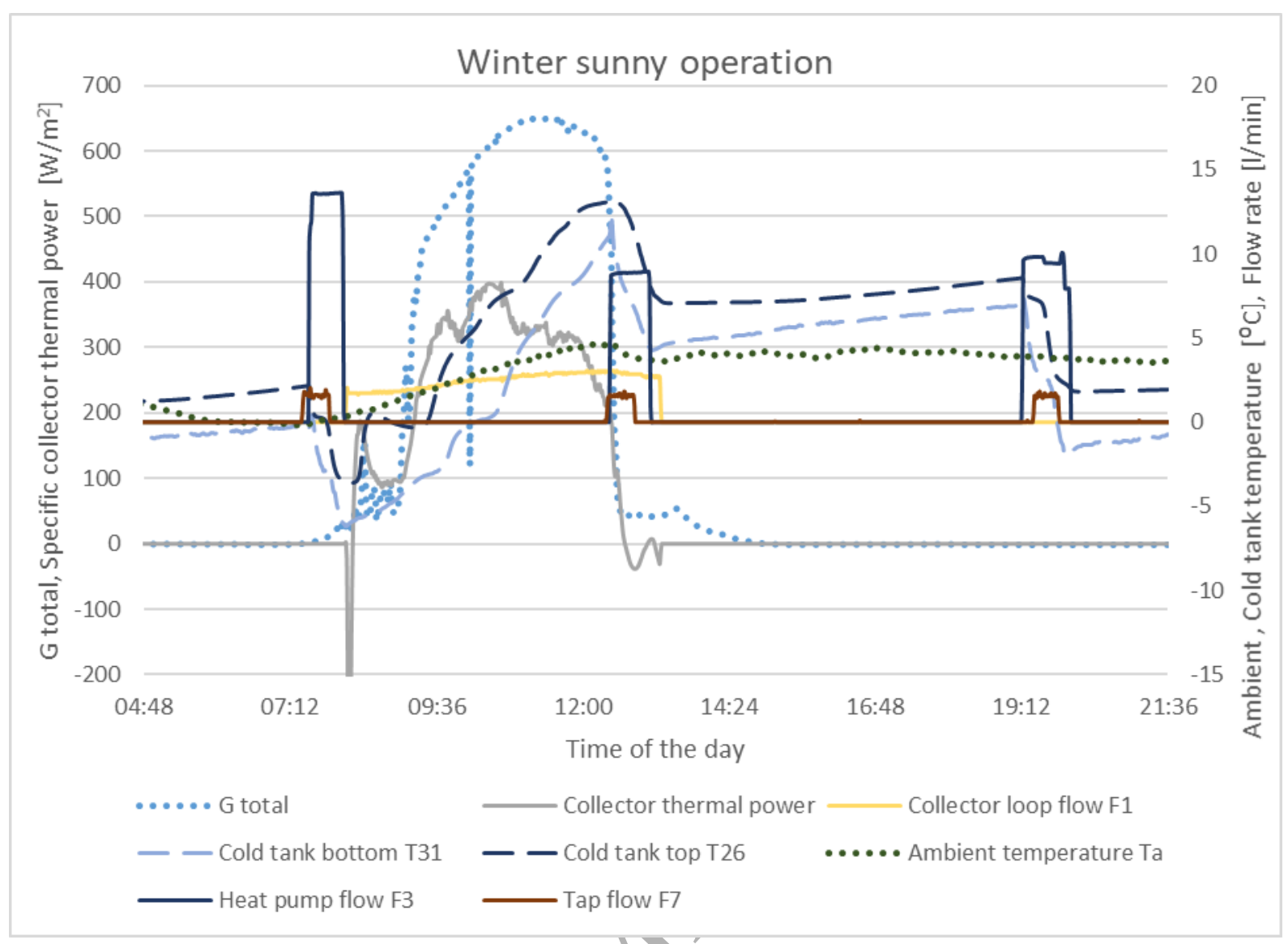

Figure 12. Example of operation in sunny conditions in winter.

The heat pump ran each time for 35-40 minutes to recharge the DHW tank after the tapings at 7:00 and 12:30. After the tapping at 7:00 the top of the cold storage tank was cooled from $2{ }^{\circ} \mathrm{C}$ to $-3^{\circ} \mathrm{C}$. The ambient temperature at this time was $0{ }^{\circ} \mathrm{C}$. The inlet to the cold side of the heat pump was from the top of the cold storage tank. The instantaneous COP at this charge peaked at 2.3 after the heat pump had been running for 20 minutes. As the temperature in the buffer tank dropped, the COP decreased to 1.9 before the heat pump stopped. The solar radiation heated the buffer storage tank to $13^{\circ} \mathrm{C}$ during the day. After the tapping at 12:30 the heat pump operated with at COP up to 3.4 dropping to 2.3 as the cold tank and the inlet to heat pump decreased to $7^{\circ} \mathrm{C}$ while the ambient temperature was $4{ }^{\circ} \mathrm{C}$.

The heat pump operated with a cold side inlet of up to $4 \mathrm{~K}$ below the ambient temperature when there was no solar radiation available. In the periods with solar irradiance, the heat pump could benefit from an inlet temperature to the cold side of the heat pump somewhat higher than the ambient temperature. In this case 4-10 K.

Figure 13 shows an example of the electrical power consumption and thermal power delivery to the DHW tank by the heat pump as well as the cold side inlet temperature and COP. It can be seen that the source temperature dropped from $8^{0} \mathrm{C}$ to $3^{0} \mathrm{C}$ during the operation. The initial peaks were due to indoor temperature liquid in the pipes between the heat pump and the storage tanks. The heat delivered to the DHW tank was measured just before the heat exchange of the DHW tank at $\mathrm{T} 18$ and T18x. The flow rate on the source side of the heat pump was $7 \mathrm{l} / \mathrm{min}$ during this operation. The temperature decreased $6 \mathrm{~K}$ on the cold side of the heat pump during the operation. The 
temperature in the cold tank dropped continuously from the start, therefore the inlet to the tank must have caused mixing in the tank. An inlet not causing mixing may have resulted in a higher inlet temperature for the operation period. Operation was for $40 \mathrm{~min}$ with a flow rate of $7 \mathrm{l} / \mathrm{min}$, in this case a tank size of at least $\mathbf{2 8 0}$ litres would have been used to only circulate the fluid one time.

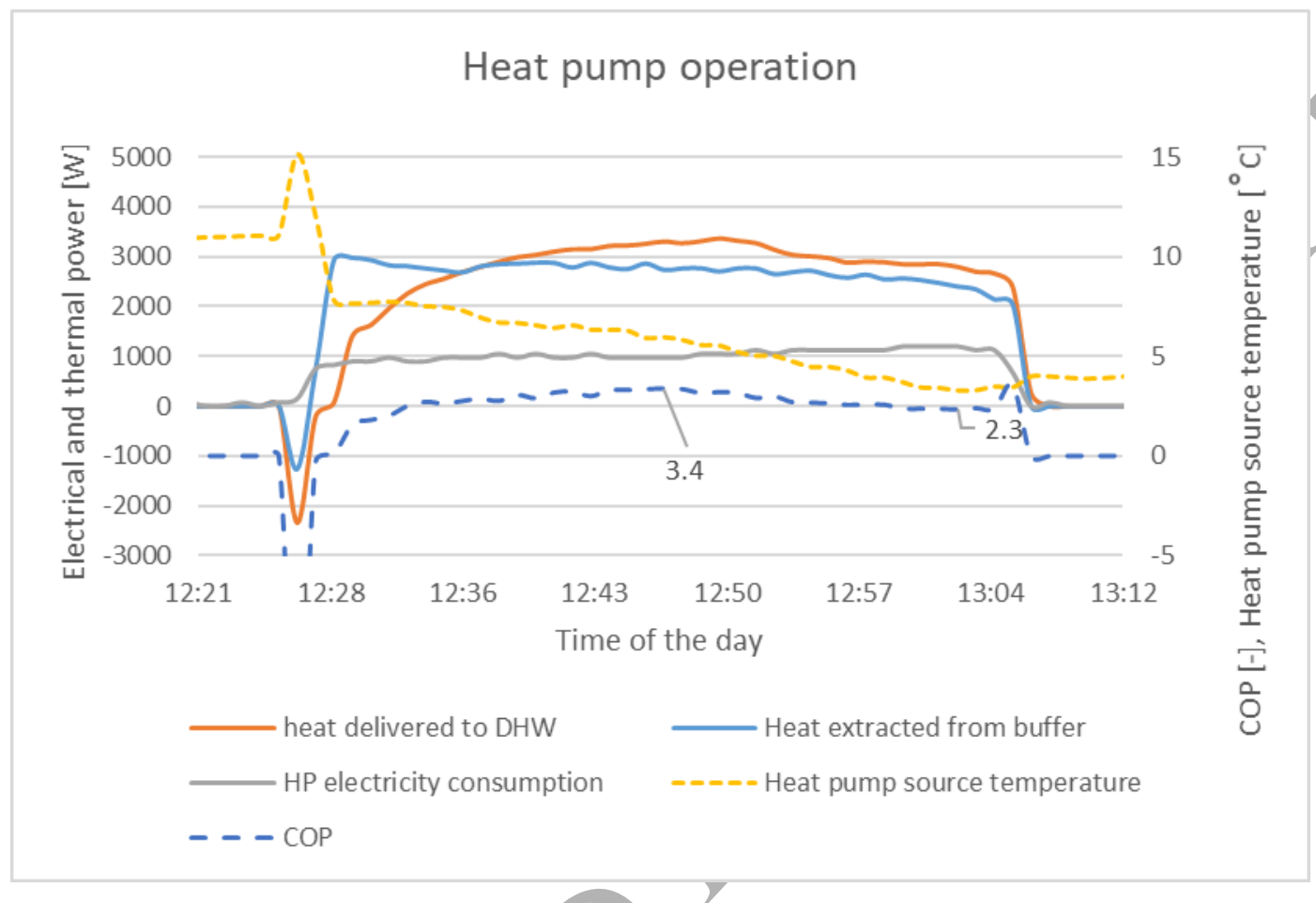

Figure 13. Example of electrical power consumption, thermal power delivered to DHW tank, cold side inlet temperature to heat pump and COP at heat pump operation in winter.

\subsection{Final discussions}

The analysis showed that the principle of solar PVT assisted two-tank heat pump system with the energy absorber function worked. However, the control strategy was not optimal and an improved control strategy would result in a better performance of the system. In addition, the component sizes and designs as well as the pipe lengths and sizes in the lab system caused significant extra losses, which reduced the performance of the system. The cold buffer storage tank need to be large enough so that the temperature in it does not drop significantly below the ambient air temperature as the heat pump runs. Sizing of the cold storage tank similar to the volume passing through the cold side of the heat pump during one charge period is suggested. In addition, an inlet design in the cold storage tank that limits mixing and results in a steep thermocline moving upwards can be beneficial to keep the cold side inlet temperature to the heat pump high and thereby the COP as high as possible. A mixing valve on the pipe loop between the heat pump and the cold buffer storage could allow for higher temperatures is the buffer storage if the forward flow temperature to the heat pump is mixed with the outlet from the cold side of the heat pump. This would lead to more heat stored in the system and potentially higher seasonal performance. A system design also intended to cover a space heating demand along with the DHW demand could also potentially allow for fewer losses associated with the short operation periods of the heat pump. Further experimental and simulation investigations can show performances of similar systems with improved component sizes and control strategy. 


\section{Conclusions}

The experimental system investigation showed that the uninsulated PVT collectors worked as both solar thermal collectors in sunny periods and as energy absorbers (heat exchangers with the ambient) in periods with solar irradiance below $50 \mathrm{~W} / \mathrm{m}^{2}$. During sunny days in summer the energy for the DHW draw offs were mainly covered by direct heat from the thermal absorber of the PVT collector. In October to January up to $0.4 \mathrm{kWh} / \mathrm{m}^{2} /$ day of heat was transferred to the cold buffer storage tank by the PVT collector operating as energy absorber, when the solar irradiance was below $50 \mathrm{~W} / \mathrm{m}^{2}$. This corresponded to approximately $60 \%$ of the heat delivered to the system by the PVT collectors in the months of January and February was with the collectors operating as energy absorbers.

As the heat pump charged the DHW tank after a DHW draw off and discharged the cold tank the PVT collector was working as energy absorber and reheated the cold tank to ambient temperatures in periods with low solar irradiance. The cold buffer storage tank connected to the cold side of the heat pump worked well as the source for the brine-to-water heat pump, however the design of the system could be improved to reduce thermal losses. The COP of the heat pump was affected by the temperature in the cold storage tank and a larger tank with better inlet designs for improved stratification could enhance the performance of the system. The lab system has proven the system type but by optimizing the component sizing and control a larger solar energy savings and solar fraction can be achieved.

\section{Acknowledgement}

The research was financed by the Danish Energy agency through EUDP grant no. 64017-05157. The PVT panels were manufactured by RACELL Technologies.

\section{References}

[1] S. Poppi, C. Bales, M.Y. Haller, A. Heinz, Influence of boundary conditions and component size on electricity demand in solar thermal and heat pump combisystems, Appl. Energy. 162 (2016) 1062-1073. doi:10.1016/j.apenergy.2015.10.190.

[2] G. Emmi, A. Zarrella, M. De Carli, A. Galgaro, An analysis of solar assisted ground source heat pumps in cold climates, Energy Convers. Manag. 106 (2015) 660-675. doi:10.1016/j.enconman.2015.10.016.

[3] H.A. Zondag, Flat-plate PV-Thermal collectors and systems: A review, Renew. Sustain. Energy Rev. 12 (2008) 891-959. doi:10.1016/j.rser.2005.12.012.

[4] G.N. Tiwari, R.K. Mishra, S.C. Solanki, Photovoltaic modules and their applications: A review on thermal modelling, Appl. Energy. 88 (2011) 2287-2304. doi:10.1016/j.apenergy.2011.01.005.

[5] V. V. Tyagi, S.C. Kaushik, S.K. Tyagi, Advancement in solar photovoltaic/thermal (PV/T) hybrid collector technology, Renew. Sustain. Energy Rev. 16 (2012) 1383-1398. doi:10.1016/j.rser.2011.12.013.

[6] A. Kumar, P. Baredar, U. Qureshi, Historical and recent development of photovoltaic thermal (PVT) technologies, Renew. Sustain. Energy Rev. 42 (2015) 1428-1436. doi:10.1016/j.rser.2014.11.044.

[7] P. Xu, X. Zhang, J. Shen, Y. Wu, K. Connelly, T. Yang, L. Tang, M. Xiao, Y. Wei, A review of 
thermal absorbers and their integration methods for the combined solar photovoltaic/thermal (PV/T) modules, Renew. Sustain. Energy Rev. 75 (2017) 839-854. doi:10.1016/j.rser.2016.11.063.

[8] T. Yang, A.K. Athienitis, A review of research and developments of building-integrated photovoltaic/thermal (BIPV/T) systems, Renew. Sustain. Energy Rev. 66 (2016) 886-912. doi:10.1016/j.rser.2016.07.011.

[9] T.M. Sathe, A.S. Dhoble, A review on recent advancements in photovoltaic thermal techniques, Renew. Sustain. Energy Rev. 76 (2017) 645-672. doi:10.1016/j.rser.2017.03.075.

[10] N. Aste, C. del Pero, F. Leonforte, Water flat plate PV-thermal collectors: A review, Sol. Energy. 102 (2014) 98-115. doi:10.1016/j.solener.2014.01.025.

[11] R. Daghigh, M.H. Ruslan, K. Sopian, Advances in liquid based photovoltaic/thermal (PV/T) collectors, Renew. Sustain. Energy Rev. 15 (2011) 4156-4170. doi:10.1016/j.rser.2011.07.028.

[12] J.J. Michael, I. S, R. Goic, Flat plate solar photovoltaic-thermal (PV/T) systems: A reference guide, Renew. Sustain. Energy Rev. 51 (2015) 62-88. doi:10.1016/j.rser.2015.06.022.

[13] A.H.A. Al-Waeli, K. Sopian, H.A. Kazem, M.T. Chaichan, Photovoltaic/Thermal (PV/T) systems: Status and future prospects, Renew. Sustain. Energy Rev, 77 (2017) 109-130. doi:10.1016/j.rser.2017.03.126.

[14] M.A. Hasan, K. Sumathy, Photovoltaic thermal module concepts and their performance analysis: A review, Renew. Sustain. Energy Rev. 14 (2010) 1845-1859. doi:10.1016/j.rser.2010.03.011.

[15] SHC Task 35, PV/Thermal systems, (n.d.). http://task35.iea-shc.org/publications (accessed October 4, 2018).

[16] SHC Task 60, Application of PVT collectors, (n.d.). http://task60.iea-shc.org/ (accessed October 4, 2018).

[17] SHC Task 44, Solar Heat Pump Systems, (n.d.). http://task44.iea-shc.org/publications (accessed November 21, 2018)

[18] S.R. Asaee, V.I. Ugursal, I. Beausoleil-Morrison, Techno-economic assessment of solar assisted heat pump system retrofit in the Canadian housing stock, Appl. Energy. 190 (2017) 439-452. doi:10.1016/j.apenergy.2016.12.053.

[19] C.J. Banister, M.R. Collins, Development and performance of a dual tank solar-assisted heat pump system, Appl. Energy. 149 (2015) 125-132. doi:10.1016/j.apenergy.2015.03.130.

[20] B. Agrawal, G.N. Tiwari, Optimizing the energy and exergy of building integrated photovoltaic thermal (BIPVT) systems under cold climatic conditions, Appl. Energy. 87 (2010) 417-426. doi:10.1016/j.apenergy.2009.06.011.

[21] A. del Amo, A. Martínez-Gracia, A.A. Bayod-Rújula, J. Antoñanzas, An innovative urban energy system constituted by a photovoltaic/thermal hybrid solar installation: Design, simulation and monitoring, Appl. Energy. 186 (2017) 140-151. doi:10.1016/j.apenergy.2016.07.011.

[22] C. Fraga, P. Hollmuller, F. Mermoud, B. Lachal, Solar assisted heat pump system for multifamily buildings: Towards a seasonal performance factor of 5 ? Numerical sensitivity analysis based on a monitored case study, Sol. Energy. 146 (2017) 543-564. doi:10.1016/j.solener.2017.02.008.

[23] P. Dupeyrat, C. Ménézo, S. Fortuin, Study of the thermal and electrical performances of PVT 
solar hot water system, Energy Build. 68 (2014) 751-755. doi:10.1016/j.enbuild.2012.09.032.

[24] M. Qu, J. Chen, L. Nie, F. Li, Q. Yu, T. Wang, Experimental study on the operating characteristics of a novel photovoltaic/thermal integrated dual-source heat pump water heating system, Appl. Therm. Eng. 94 (2016) 819-826.

doi:10.1016/j.applthermaleng.2015.10.126.

[25] L. Dai, S. Li, L. DuanMu, X. Li, Y. Shang, M. Dong, Experimental performance analysis of a solar assisted ground source heat pump system under different heating operation modes, Appl. Therm. Eng. 75 (2015) 325-333. doi:10.1016/j.applthermaleng.2014.09.061.

[26] G. Panaras, E. Mathioulakis, V. Belessiotis, Investigation of the performance of a combined solar thermal heat pump hot water system, Sol. Energy. 93 (2013) 169-182. doi:10.1016/j.solener.2013.03.027.

[27] X. Yang, L. Sun, Y. Yuan, X. Zhao, X. Cao, Experimental investigation on performance comparison of PV/T-PCM system and PV/T system, Renew. Energy. 119 (2018)152-159. doi:10.1016/j.renene.2017.11.094.

[28] K.R. Gautam, G.B. Andresen, Performance comparison of building-integrated combined photovoltaic thermal solar collectors (BiPVT) with other building-integrated solar technologies, Sol. Energy. 155 (2017) 93-102. doi:10.1016/j.solener.2017.06.020.

[29] R.S. Kamel, A.S. Fung, P.R.H. Dash, Solar systems and their integration with heat pumps: A review, Energy Build. 87 (2015) 395-412. doi:10.1016/j.enbuild.2014.11.030.

[30] J. Cai, J. Ji, Y. Wang, F. Zhou, B. Yu, A novel PV/T-air dual source heat pump water heater system: Dynamic simulation and performance characterization, Energy Convers. Manag. 148 (2017) 635-645. doi:10.1016/j.enconman.2017.06.036.

[31] G. Xu, S. Deng, X. Zhang, L. Yang, Y. Zhang, Simulation of a photovoltaic/thermal heat pump system having a modified collector/evaporator, Sol. Energy. 83 (2009) 1967-1976. doi:10.1016/j.solener.2009.07.008.

[32] J. Ji, K. Liu, T. tai Chow, G. Pei, W. He, H. He, Performance analysis of a photovoltaic heat pump, Appl. Energy. 85 (2008) 680-693. doi:10.1016/j.apenergy.2008.01.003.

[33] L. Keliang, J. Jie, C. Tin-tai, P. Gang, H. Hanfeng, J. Aiguo, Y. Jichun, Performance study of a photovoltaic solar assisted heat pump with variable-frequency compressor - A case study in Tibet, Renew. Energy. 34 (2009) 2680-2687. doi:10.1016/j.renene.2009.04.031.

[34] T.T. Chow, K.F. Fong, G. Pei, J. Ji, M. He, Potential use of photovoltaic-integrated solar heat pump system in Hong Kong, Appl. Therm. Eng. 30 (2010) 1066-1072. doi:10.1016/j.applthermaleng.2010.01.013.

[35] M. Dannemand, S. Furbo, B. Perers, K. Kadim, S.E. Mikkelsen, Performance of a Solar Heating System with Photovoltaic Thermal Hybrid Collectors and Heat Pump, in: IAFOR Int. Conf. Sustain. Energy Environ. - Hawaii 2017, 2017. 